\title{
Long-Term Dynamics of Ozone in Surface Atmosphere at Remote Mountain, Rural and Urban Sites of South-East Siberia, Russia
}

\author{
Olga Khuriganova1, Vladimir Obolkin', Hajime Akimoto², Tsuyoshi Ohizumi2,3, \\ Tamara Khodzher ${ }^{1}$, Vladimir Potemkin ${ }^{1}$, Liudmila Golobokova ${ }^{1}$ \\ ${ }^{1}$ Limnological Institute, Siberian Branch of Russian Academy of Sciences, Irkutsk, Russia \\ ${ }^{2}$ Asia Centre for Air Pollution Research, Niigata, Japan \\ ${ }^{3}$ Niigata Prefectural Institute for Public Health and Environmental Sciences, Niigata, Japan \\ Email: obolkin@lin.irk.ru
}

Received 5 April 2016; accepted 19 April 2016; published 22 April 2016

Copyright (C) 2016 by authors and OALib.

This work is licensed under the Creative Commons Attribution International License (CC BY). http://creativecommons.org/licenses/by/4.0/

(c) (i) Open Access

\section{Abstract}

Long-term monitoring of near-ground ozone concentration was performed in the remote mountain area as well as at rural and urban sites of South-East Siberia. Ozone concentrations at all three sites had similar seasonal dynamics with its maximum in spring and minimum in autumn. Such seasonal trends were characteristic of many areas of the Northern Hemisphere. Diurnal fluctuations of ozone concentrations were caused by photochemical generation of ozone at daytime and its partial depletion at night. Diurnal fluctuations were maximal in spring and summer and minimal in December and January in accordance with solar radiation intensity. At the urban site, mean ozone concentrations were significantly lower (about 2 times) than those in the rural and background areas. This was likely attributed to the increased consumption of ozone for oxidation of air pollutants in the urbanized area. A tendency to the decrease of mean annual ozone concentrations was recorded during long-term observations at the mountain site Mondy.

\section{Keywords}

Ozone, Nitrogen Oxide, Solar Radiation, Monitoring, East Siberia

Subject Areas: Atmospheric Sciences, Environmental Sciences

\section{Introduction}

The key function of ozone on the Earth is to absorb ultraviolet solar radiation by a stratospheric ozone layer (approximately $90 \%$ of total ozone). For the past decades, the rise of concentrations of tropospheric (surface)

How to cite this paper: Khuriganova, O., Obolkin, V., Akimoto, H., Ohizumi, T., Khodzher, T., Potemkin, V. and Golobokova, L. (2016) Long-Term Dynamics of Ozone in Surface Atmosphere at Remote Mountain, Rural and Urban Sites of South-East Siberia, Russia. Open Access Library Journal, 3: e2578. http://dx.doi.org/10.4236/oalib.1102578 
ozone has been registered in many areas of the world [1]-[4]. Elevated concentrations of surface ozone as the strongest oxidizer can negatively affect human health and land vegetation (at concentration higher than 40 - 60 $\mathrm{ppb}$ ). Moreover, tropospheric ozone is one of the greenhouse gases, which can contribute to global warming. Most chemical reactions in the atmosphere are governed by tropospheric ozone. One of the main reasons of the rise of tropospheric ozone concentrations is general increase in atmosphere pollution. From the beginning of the industrial revolution till present, average ozone concentrations have increased from $10-20 \mathrm{ppb}$ to 40 - $60 \mathrm{ppb}$ [1]. Photochemical reactions with the involvement of anthropogenic nitrogen and carbon oxides and volatile organic compounds are considered to be a source of additional accumulation of tropospheric ozone [5]-[7]. However, inverse effect of ozone depletion under the influence of anthropogenic pollutionis is also possible. Therefore, studies of processes of formation and sink of surface ozone, as well as its seasonal and long-term variability are important for estimation and forecast of possible ecological changes in different natural environments.

The aim of the present work is to compare results obtained during long-term observations of surface ozone concentrations in three areas of East Siberia differing in the level of anthropogenic atmosphere pollution: the remote background mountain area (Station Mondy), rural area (Station Listvyanka) and urbanized area (Station Irkutsk).

\section{Sampling Sites and Methods}

Long-term measurements of ozone concentrations were performed at 3 atmospheric monitoring sites in the south of East Siberia within the framework of the International EANET Programme (http://www.eanet.asia): Station Mondy-background mountain conditions, Station Listvyanka—rural conditions and Station Irkutsk—urban conditions (Figure 1).

Station Mondy $\left(51^{\circ} 40^{\prime} \mathrm{N} ; 101^{\circ} 0^{\prime} \mathrm{E}\right)$ is located on Mount Chasovye Sopki (the plateau between the East Sayan and Khamar-Daban ridges, 2,005 m above sea level) near the Astronomic Observatory of the Institute of SolarTerrestrial Physics SB RAS. This area is not affected by any local sources of atmosphere pollution, being at a distance of $250 \mathrm{~km}$ from industrial enterprises of the region. This station characterizes regional background conditions of atmosphere and global transfer of atmospheric impurities.

Station Listvyanka ( $51^{\circ} 51^{\prime} \mathrm{N}$; $\left.104^{\circ} 54^{\prime} \mathrm{E}\right)$ is situated $70 \mathrm{~km}$ from the city of Irkutsk, on the south-western shore of Lake Baikal. The station is located beyond the settlement Listvyanka at the top of the hill, $250 \mathrm{~m}$ above the lake surface. The population of Listvyanka is approximately 3000 people. For the past years, tourism has been intensely developed in this area. A few point sources of pollution are located in the settlement such as small boiler plants and stove heating. The he atmosphere in this area is periodically polluted by transport of anthropo-

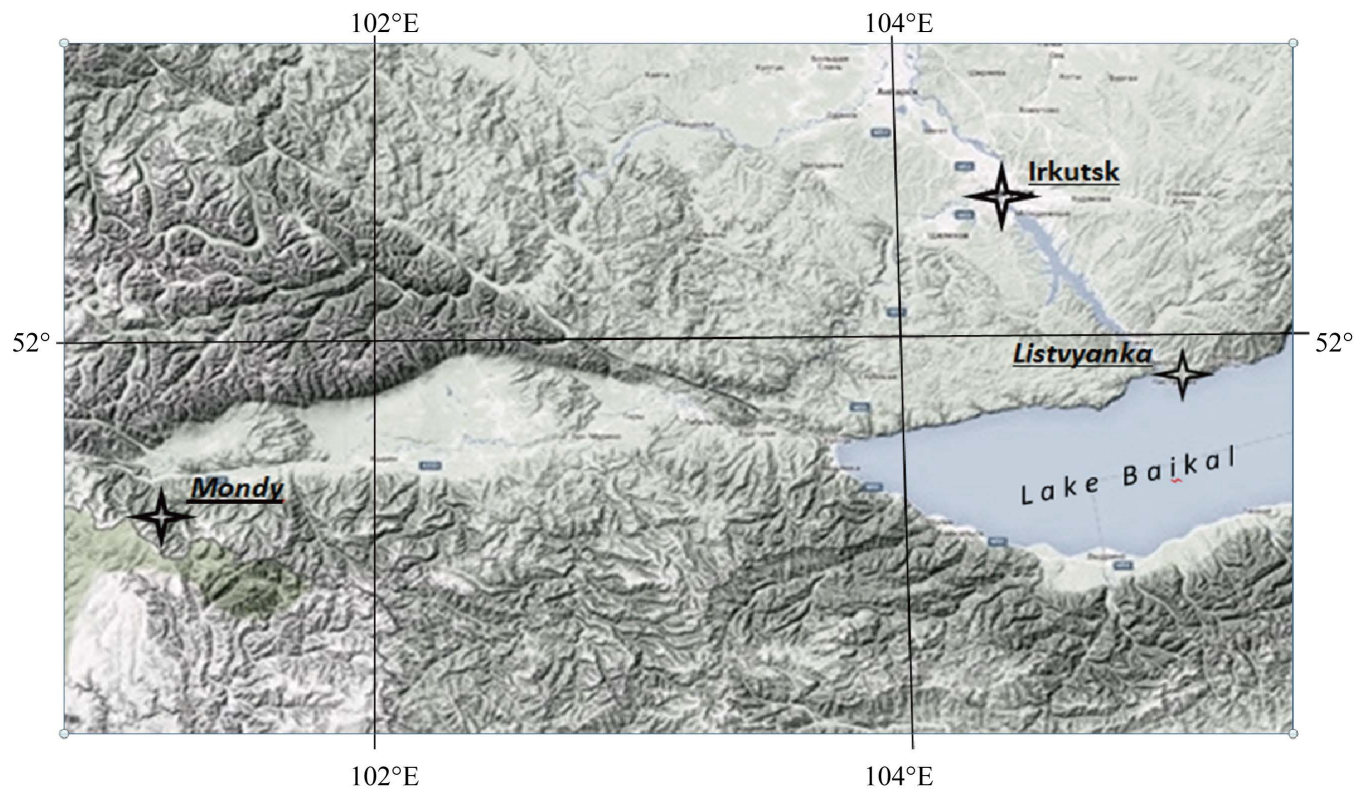

Figure 1. Location of monitoring sites. 
genic emissions from large regional cities-Irkutsk and Angarsk, which are 70 - $100 \mathrm{~km}$ to the north-west of the settlement.

Station Irkutsk ( $\left.52^{\circ} 14^{\prime} \mathrm{N} ; 104^{\circ} 15^{\prime} \mathrm{E}\right)$ is located in Irkutsk, a large industrial centre in the south of East Siberia, with the population of over 600,000 people. The city possesses 196 industrial and municipal boiler plants and a large Heat Power Electric Plant (HPEP). The contribution of these sources is $86 \%$ of the total discharge of all atmospheric emission of this urban area. Observations were performed at the southern end of the city. The data obtained from this station characterize the conditions of industrial regions of Siberia.

Ozone was measured at these three stations using both passive and active sampling methods. Since autumn of 1996, the researchers of Limnological Institute SB RAS (Russia) and Research Centre for Science and Technology at Tokyo University have been monitoring ozone at the mountain station Mondy. Seasonal and diurnal dynamics of surface ozone concentration (SOC) was studied under background conditions of the continental climate. Automatic control of ozone content in atmosphere (active sampling) was performed using an optical ozone meter "Dylec" Model 1007-AHJ. Instrument error was no higher than 10\%. Since 1997, measurements have been conducting permanently with 1 hour time resolution.

Besides instrumental methods of ozone measurement, simpler and universal passive sampling methods were also used. At present, the passive sampling of ozone is used in some countries and monitoring networks (WMO, EANET) for monitoring air quality in offices, dwelling houses and polluted cities to determine the dose effect on vegetation [8]-[11]. During passive sampling pollutants are accumulated onto an impregnated filter. A typical scheme of passive sampling was described in [9]. The salt solution $\mathrm{NO}-\mathrm{NO}_{2}+\mathrm{K}_{2} \mathrm{CO}_{3}$ was used as an ozone absorbent. In our studies, filters were exposed for two weeks, so the time resolution of the method was 2 weeks. Before chemical analysis, samples were extracted from each filter by $10 \mathrm{ml}$ distilled water during $20 \mathrm{~min}$. The extract then was filtered through a $0.45 \mu \mathrm{m}$ filter. Concentrations of nitrate ion $\left(\mathrm{NO}_{3}^{-}\right)$were determined from the filtrate using a high-performance liquid ion chromatograph "Milichrom A-02". Ozone concentrations were calculated from the quantity of nitrates determined. Since 2010, ozone has been monitored by passive method at all 3 stations using this method.

A disadvantage of passive sampling is low time resolution (from a week to two weeks). Therefore, sometimes an automatic optic analyzer "Dylec", Model 1007-AHJ (Japan) was used to estimate shorter variation periods of ozone concentrations at stations Irkutsk (in 2010) and Listvyanka (since December of 2013). At Station Listvyanka ozone concentrations were automatically measured every $5 \mathrm{~min}$ as well as meteorological parameters: total solar radiation (as one of the main factors of photochemical formation of ozone), atmospheric pressure, humidity, wind direction and velocity were automatically recorded too.

The comparison of passive and active (automatic) data shows satisfactory coincidence of both methods. Average monthly concentrations for Station Irkutsk in 2010 (Table 1) measured by both methods differed in accuracy range of $20 \%$ [12].

The same comparison for Station Mondy for 2010-2014 (Figure 2) demonstrates good similarity of seasonal and long-term variability of ozone. However, significant discrepancies (over 2 standard deviations) were recorded in separate months. The most probable reason of these deviations is an error of passive method associated probably with a "human factor" at the stage of sampling, transportation and storage of samples, and sample analysis in the laboratory. Nevertheless, this method may appear to be a good alternative for more costly automatic methods, especially in remote and hard-to-reach areas.

Table 1. Comparison of $\mathrm{O}_{3}$ measurements by passive and active methods. Irkutsk, 2010.

\begin{tabular}{cccccccc}
\hline Period & $\begin{array}{c}\text { Automatic } \\
\text { ppbv, } \mathrm{X} \pm \sigma\end{array}$ & $\begin{array}{c}\text { Passive } \\
\text { ppbv }\end{array}$ & $\begin{array}{c}\text { Differences } \\
(\%)\end{array}$ & Period & $\begin{array}{c}\text { Automatic } \\
\text { ppbv, X } \pm \sigma\end{array}$ & $\begin{array}{c}\text { Passive } \\
\text { ppbv }\end{array}$ & $\begin{array}{c}\text { Differences } \\
(\%)\end{array}$ \\
\hline January & $16.7 \pm 8.2$ & 17.4 & -4 & July & $12.3 \pm 3.0$ & 10.2 & 21 \\
February & $10.8 \pm 6.6$ & 14.1 & -23 & August & $12.7 \pm 3.5$ & 14.2 & -11 \\
March & $19.2 \pm 4.7$ & 16.7 & 15 & September & $12.4 \pm 3.4$ & 16.2 & -23 \\
April & $25.2 \pm 2.9$ & 24.6 & 2 & October & $14.3 \pm 2.9$ & 16.9 & -15 \\
May & $20.7 \pm 4.7$ & 19.5 & 6 & November & $23.4 \pm 10.2$ & 19.4 & 20 \\
June & $14.9 \pm 4.8$ & 14.6 & 2 & December & $16.1 \pm 9.4$ & 15.2 & 6
\end{tabular}




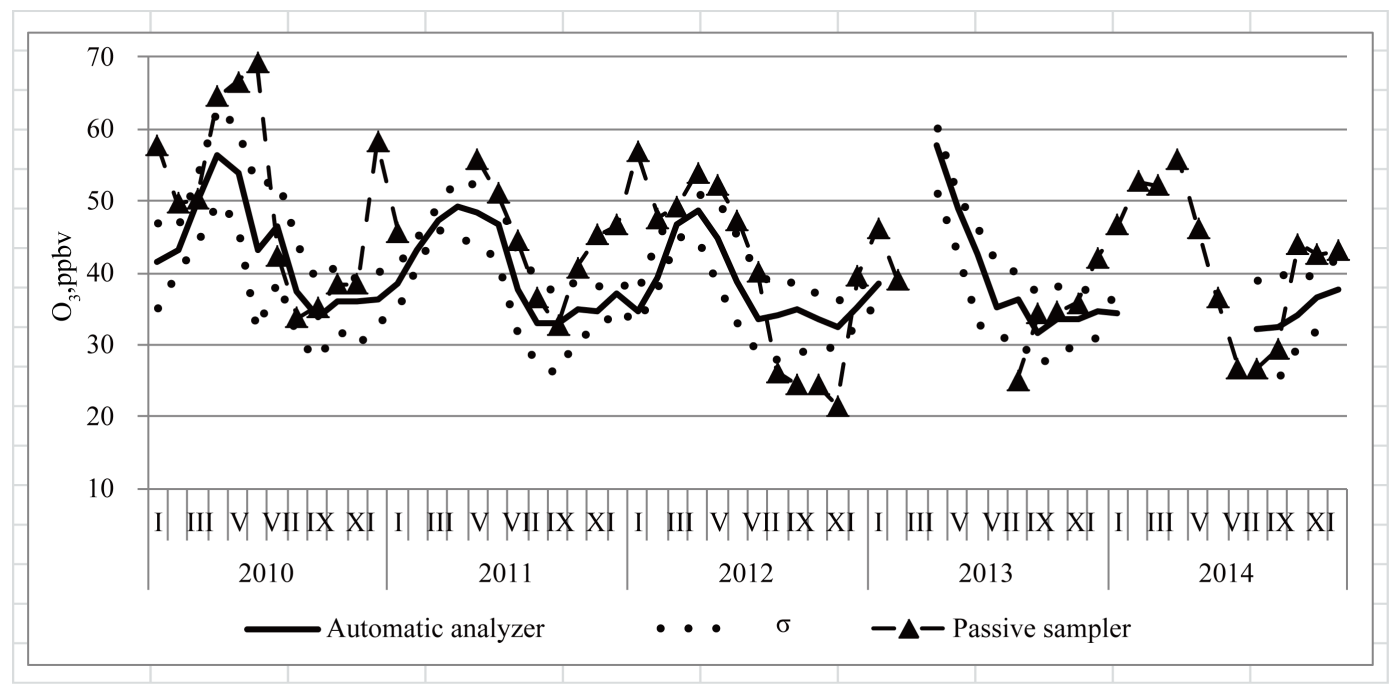

Figure 2. Comparison of ozone concentrations by passive and active (automatic) methods at Station Mondy.

\section{Results and Discussions}

\subsection{Seasonal Variability}

According to passive measurements, annual dynamics of ozone concentrations at three stations in 2010-2013 was typical of many areas of the Northern Hemisphere [1] [2] [6] with its maximum in spring (April-May) and minimum in autumn (September-October) (Figure 3). Given that the annual trend of distribution of surface ozone in the atmosphere is similar at all three Siberian stations, average ozone concentrations appeared to be significantly lower at the urban station (Irkutsk) than those at the background station (Mondy) and rural station (Listvyanka). The most probable reason was that ozone was consumed in larger quantities for oxidation of other anthropogenic impurities within the large city.

It is known that winter-spring maximum of ozone is caused by its sink from stratosphere into troposphere [2] [15]. The decrease of ozone concentrations in summer [13]-[15] is attributed to weakening of anticyclone activity in the Siberian region. Insignificant barometric pressure gradients in the warm period cause the decrease of wind velocity. Cyclones and anticyclones are less active, and the exchange of air masses between stratosphere and troposphere slows down. At the same time, ozone depletes more intensely in summer due to ozone consumption for oxidation of organic matters, which form as a result of intense growth of vegetation, as well as due to its leaching by summer atmospheric precipitation.

Atmospheric circulation can also affect the variability of surface ozone concentrations. Figure 4 presents synchronous records of ozone concentration and atmospheric pressure at Station Listvyanka in April of 2014. Besides regular diurnal (photochemical) fluctuations of ozone concentrations, there are "longer" irregular fluctuations, which are in anti-phase with atmospheric pressure: low ozone concentrations correspond to high pressure and, vice versa, ozone content increases at low pressure. The periodicity of fluctuations makes up a few days, testifying to variations of synoptic scale and therefore it is likely to be connected with the intensity of horizontal and vertical transport of ozone by wind.

For example, strong NW winds along the Angara River valley to the south of Lake Baikal are usually caused by elevated atmospheric pressure over the Irkutsk area. This regional air mass transfer may bring polluted urban air with lower ozone concentration to the Listvyanka area (Figure 3). It is known that emissions from industrial enterprises can be a reason of short-term non-periodic fluctuations of ozone in rural and urban areas [16] [17]. Numerous observations performed at Station Listvyanka showed that anthropogenic emission plumes favoured ozone depletion rather than its formation (at least at night time). As an example, Figure 5 presents a fragment of automatic concentration registration of ozone and sulphur and nitrogen oxides in December of 2013 (with 5 minute time resolution): on December 22, the ozone concentrations were stably high (35 - $45 \mathrm{ppb}$ ) at the wind blowing from Lake Baikal. At midnight on December 23, the wind changed its direction to the north-west, and the atmospheric plume of the power plant was transported from Irkutsk over the area of Listvyanka Station. As a 


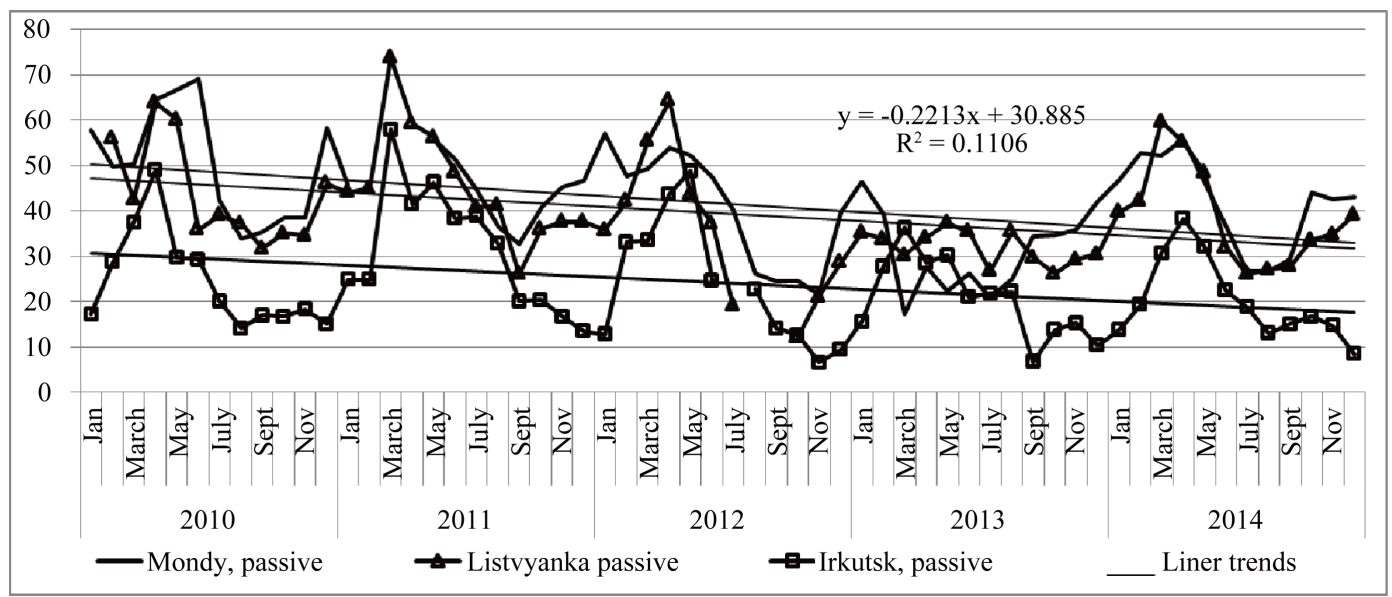

Figure 3. Seasonal variability of ozone concentrations monitored by passive sampling at three monitoring stations in East Siberia.

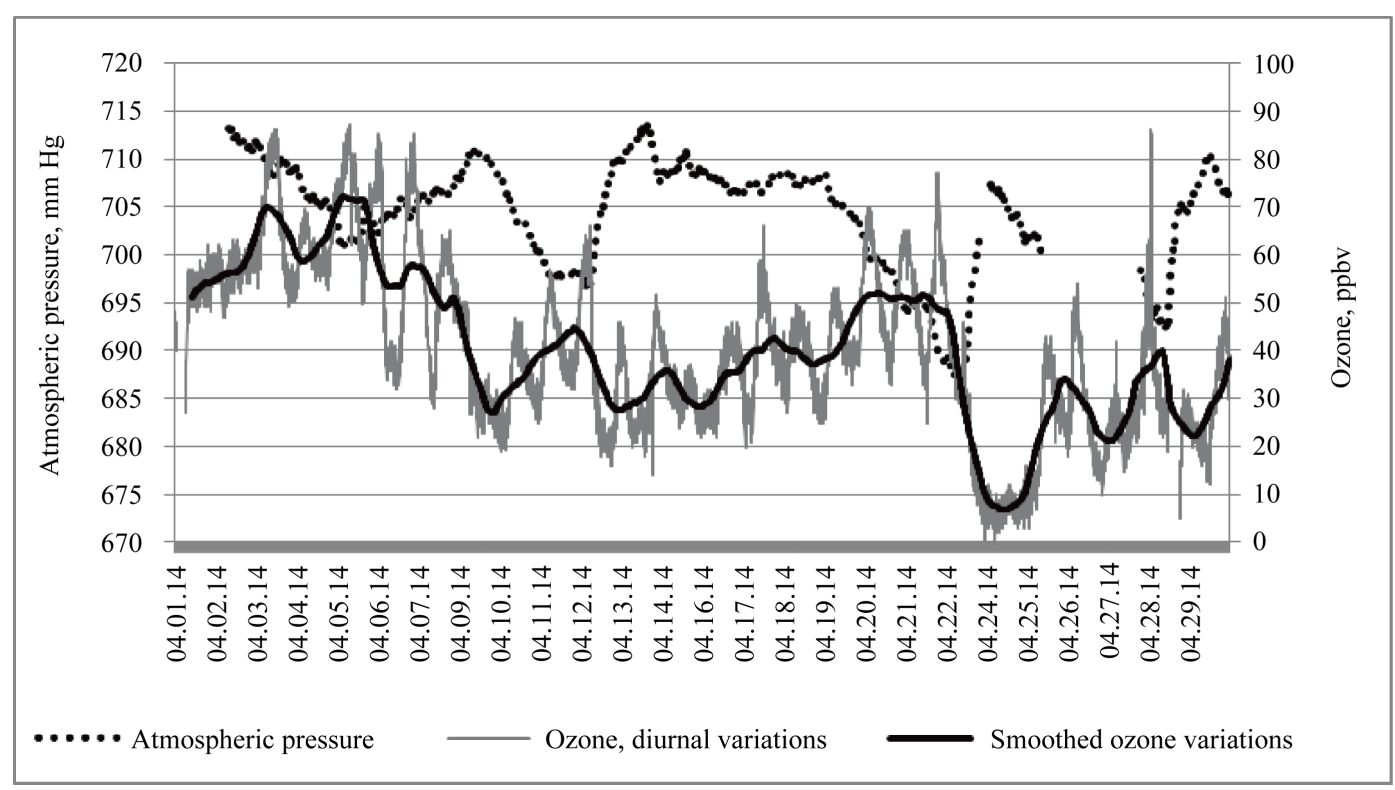

Figure 4. Dynamics of ozone concentrations and atmospheric pressure in surface atmosphere at Station Listvyanka, April of 2014.

result, the ozone content fluctuated up to zero synchronously with the rise of concentrations of sulphur and nitrogen oxides. Ozone within such plumes can completely react with nitrogen oxides. Therefore, its concentrations within the plume were close to zero.

Short-term and abrupt increases in concentrations of sulphur and nitrogen oxides at Station Listvyanka were caused by the so-called "low-level atmospheric jets", which transported weakly scattered plumes emitted from coal heat power-electric plants [18] [19]. These flows formed more often at night and in the morning in the inversion layers of atmosphere at an altitude of 200-500 $\mathrm{m}$ above ground surface (at the height of emissions from tall chimneys of large heat power electric plants). Station Listvyanka is influenced by these plumes as it is located at the altitude of the plume's transfer.

\subsection{Diurnal Variability}

Diurnal fluctuations of ozone concentration were clearly observed during a year, except December and January. These fluctuations depended on diurnal dynamics of solar radiation, which is one of the main factors of photo- 


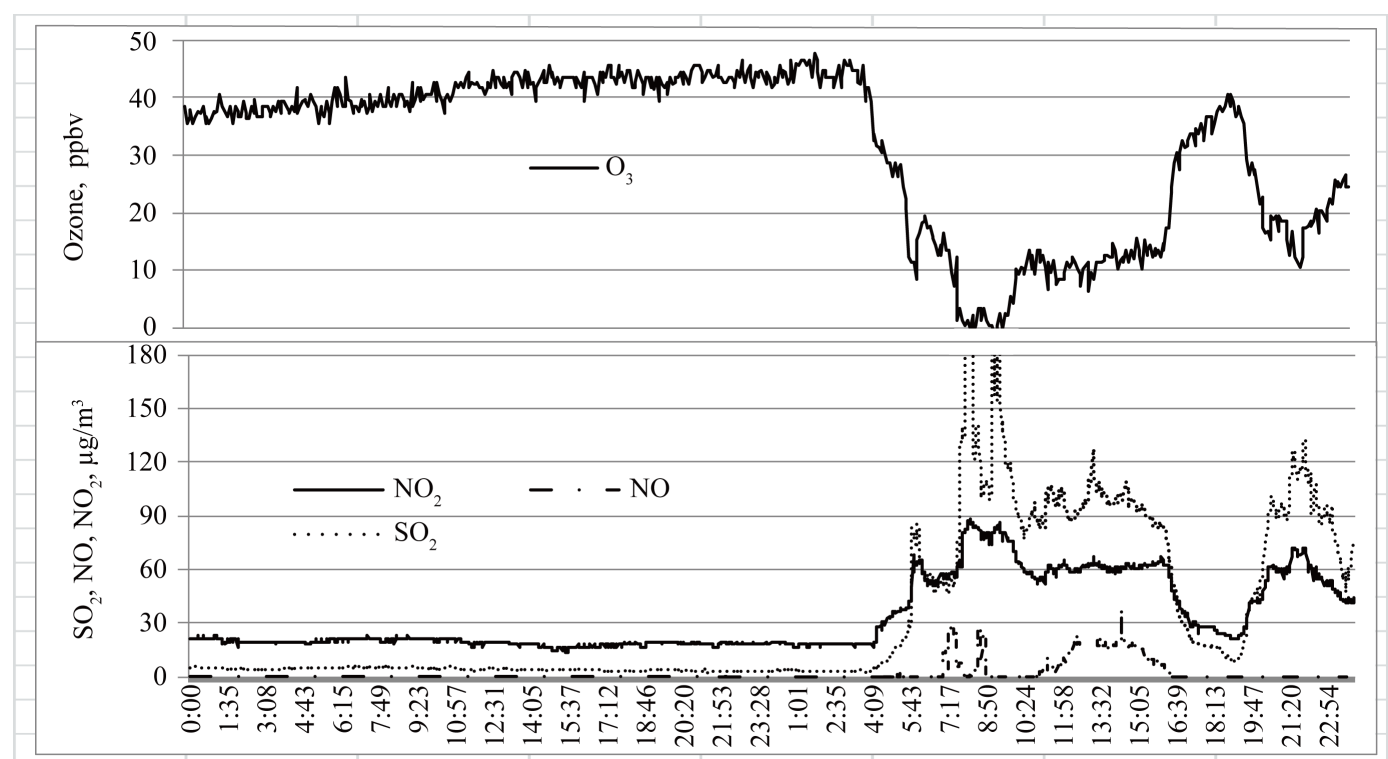

Figure 5. Fragment of ozone and nitrogen oxides concentrations records during transport of plume from the coal power-electric plant over Listvyanka station.

chemical ozone generation. Figure 6 (Station Listvyanka) demonstrates the increase in daily ozone photogeneration from winter (January) to spring (April) and summer under the influence of growing solar radiation.

Ozone generation started with the sunrise at radiation of approximately more than $200 \mathrm{~W} / \mathrm{m}^{2}$ and ended before the sunset at radiation lower than this value. Therefore, maximal concentrations of ozone were recorded in the evening. The delay of diurnal maximum of ozone with respect to the solar radiation maximum depended on the length of daylight amounting to 3 - 4 hours in February-March and 5 - 6 hours in June-July. This is well seen in the inter-correlation functions of variability of ozone and solar radiation (Figure 7), the maximal correlations being in May-June (approximately 0.6) and minimal ones in December-January (0.1). On cloudy days, as a rule, the diurnal amplitude of ozone concentration is expressed weaker than that on sunny days.

At night due to the absence of ozone photogeneration, its concentrations gradually reduced because of its consumption for oxidation processes in atmosphere or absorption by underlying surface (vegetation). Mean night ozone concentrations were 20 - $40 \mathrm{ppb}$ in spring and practically zero in September-October. In a cold season and early spring, ozone sink was minimal at night probably due to the snow cover, which prevented interaction between ozone and vegetation. In summer and autumn months, the ozone sink intensified, and in September-October, it was not compensated by lower daytime photochemical generation. Total ozone concentrations reached their minimal values.

Despite the minimal solar radiation in winter months (from January to early February), ozone concentrations were relatively high (30 - $40 \mathrm{ppb})$. In this season, the major source of ozone can be not only photochemical reactions occurring in the atmosphere but also other processes, e.g., ozone sink from the stratosphere. In March April, photochemical generation intensified due to the increase of the length of daylight. At the same time, the depletion of ozone at night was minimal because of the snow cover and low air temperature. As a result, in the surface atmosphere of East Siberia its maximal concentrations were recorded in spring.

\subsection{Long Term Trends}

The longest series of automatic ozone observations (18 years) was obtained at Station Mondy (Figure 8). During this period up to 2002-2004, the tendency to growth of ozone concentrations was registered, but after those years up to recent time the tendency to decrease of average annual ozone concentrations is clearly detected. The same tendency can be also observed analysing passive data obtained at all 3 stations during shorter periods of observations (2010-2014) (Figure 2 and Figure 3).

The long-term trends of ozone concentration at those three Siberian stations can be compared with global data from the Tropospheric Ozone Assessment Report (http://www.igacproject.org/TOAR). According this Report, 


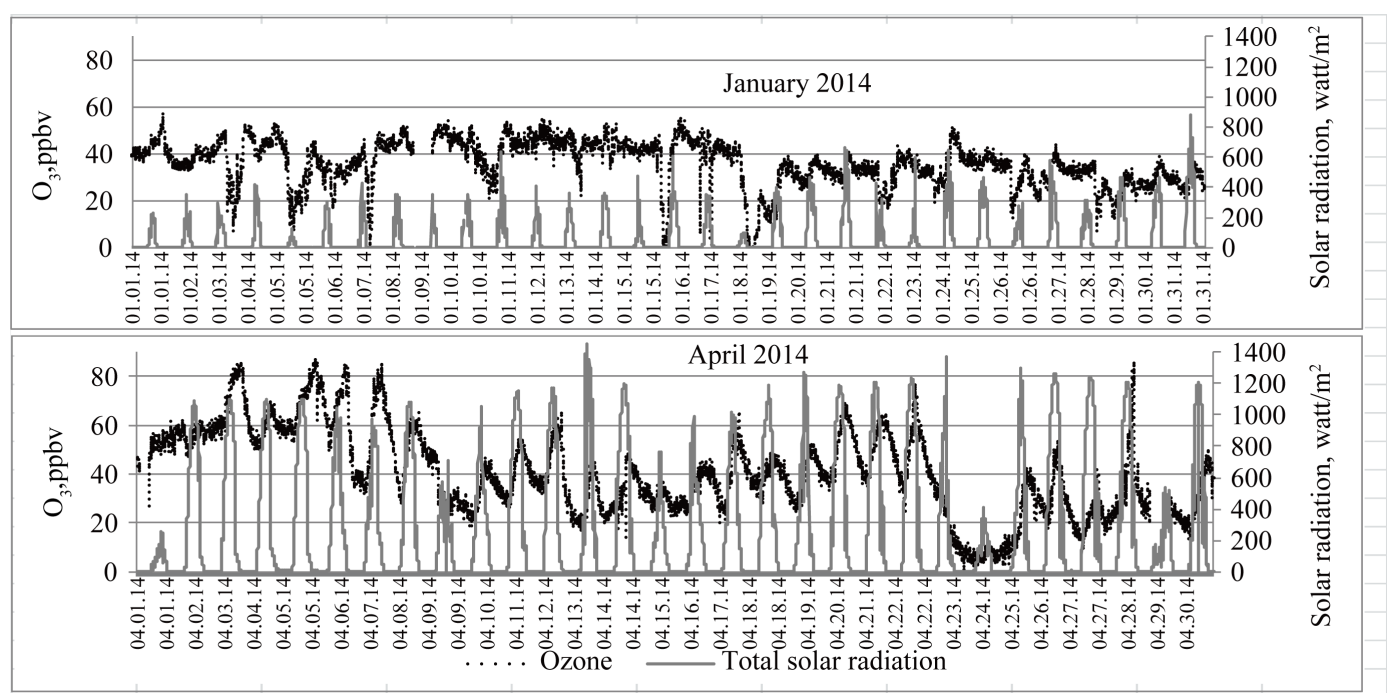

Figure 6. Diurnal variation of solar radiation and ozone concentration at Station Listvyanka.January and April of 2014.

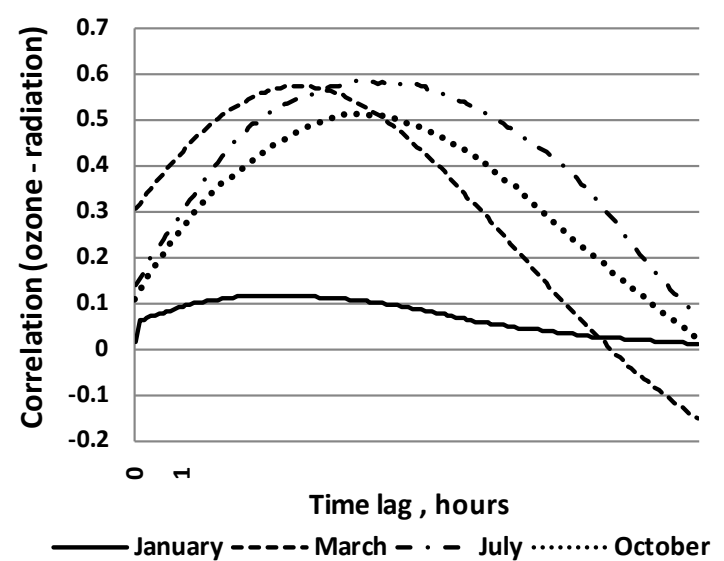

Figure 7. Correlation of solar radiation and ozone concentrations depending on hour lags for different seasons.

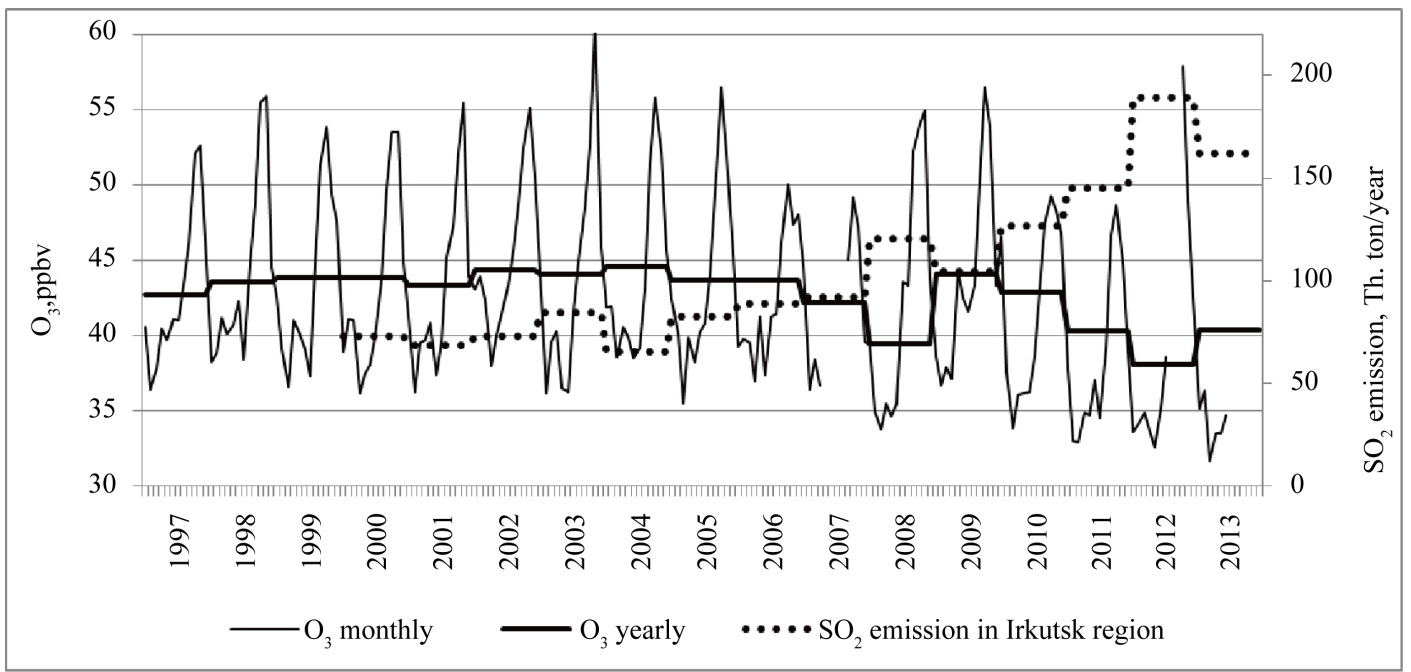

Figure 8. Long-term trend of ozone concentrations at the background Station Mondy. 
seasonal and inter-annual variability of ozone was found to be different for many stations of the world making it difficult to identify a common long-term ozone trend. Prior to the 1900, almost all records indicated a stable rise, while during the 1900 the picture was very diverse. Some data show stable or decreasing trends in northern mid-latitudes after 1980. At least in most regions surface and tropospheric ozone concentrations have not risen significantly since 2000 [20]. One of the most possible reasons of the decrease of average annual concentrations of ozone at all 3 stations in Siberia after 2006 may be a significant rise of anthropogenic emission in this area. Figure 8 shows that since 2007 average annual concentrations of ozone are in anti-correlation with annual emissions of sulphur dioxide in Irkutsk and Angarsk.

\subsection{Ozone Concentration in Comparison with Maximum Permissible Concentrations (MPC)}

Unlike stratospheric ozone, surface (tropospheric) ozone is considered an air pollutant. Therefore, maximal permissible levels have been introduced for ozone. Different standards for permissible concentrations of surface ozone exist in different countries. For example, ozone concentrations exceeding $60 \mathrm{ppb}$ for 8 hours are considered dangerous in many countries. In Europe, the so-called "cumulative dose-40" is used as a criterion of ozone danger - total concentration higher than $40 \mathrm{ppb}$. In the USA, a similar criterion exists-total concentration higher than $60 \mathrm{ppb}$ [1].

In Russia, mean daily maximal permissible ozone concentration (MPC) is $30 \mu \mathrm{g} / \mathrm{m}^{3}$ (about $15 \mathrm{ppbv}$ ), whereas single maximal permissible concentration is $160 \mu \mathrm{g} / \mathrm{m}^{3}$ ( $\left.\sim 80 \mathrm{ppb}\right)$. Thus, according to data considered above, during most part of the year mean concentrations of ozone exceeded mean diurnal MPC in the background and rural areas of South Siberia. The increase of MPC was recorded less frequently at the urban site Irkutsk.

\section{Conclusions}

Ozone concentrations in all three studied areas in the south of East Siberia have similar seasonal dynamics with its maximum in spring and minimal values in autumn. Such seasonal trends of ozone concentrations are characteristic of many areas of the Northern Hemisphere, and it is likely that there are global reasons for that: sink of stratospheric ozone during the cold period and its active depletion in the warm period. Moreover, the area under study is characterised by shorter-term fluctuations (several days) of ozone concentrations in cold period associated with synoptic conditions: atmospheric pressure and regional wind transfer.

The most expressed fluctuations are diurnal fluctuations of ozone concentrations caused by its photochemical generation under the influence of solar radiation at daytime and its partial depletion at night. The quantity of ozone formed at daytime depends on duration and intensity of solar radiation, whereas its depletion at night depends on the state of the underlying surface. Diurnal fluctuations of ozone are maximal in spring and summer and minimal in December and January.

There are differences in mean concentrations of ozone: in urban (polluted) areas mean ozone concentrations are significantly lower (about 2 times) than in rural and background areas. This is likely attributed to the increased consumption of ozone for oxidation of other air pollutants on the urbanized territory.

During the continuous observations for the past 18 years, no tendency of the increase of mean annual ozone concentrations has been recorded at the background station Mondy.

\section{Acknowledgements}

This work was fulfilled in the frame of State Contract 0345-2014-00 with Limnological Institute SB RAS (registration number: 01201353446).

\section{References}

[1] Akimoto, N. (2006) Tropospheric Ozone a Growing Threat. Acid Deposition and Oxidant Research Centre, Niigata, 26 p.

[2] Rovinsky, F.Y. and Egorov, V.I. (1986) Ozone, Oxides of Nitrogen and Sulphur in the Lower Atmosphere. L. Hydrometeoizdat, $183 \mathrm{p}$.

[3] Jacob, D.J., Logan, J.A. and Murti, P.P. (1999) Effect of Rising Asian Emission on Surface Ozone in the United States. Geophysical Research Letters, 26, 2175-2178. http://dx.doi.org/10.1029/1999GL900450 
[4] Cynthia Lin, C.-Y., Jacob, D.J., William Munger, J. and Fiore, A.M. (2000) Increasing Background Ozone in Surface Air over the United States. Geophysical Research Letters, 27, 3465-3468. http://dx.doi.org/10.1029/2000GL011762

[5] Belan, B.D. (2010) Ozone in Troposphere. Institute of Atmosphere Optics SB RAS, Tomsk, 527 p.

[6] Pochanart, P., Kato, S., Katsuno, T. and Akimoto, H. (2004) Eurasian Continental Background and Regionally Polluted Levels of Ozone and CO Observed in Northeast Asia. Atmospheric Environment, 38, 1325-1336. http://dx.doi.org/10.1016/j.atmosenv.2003.11.014

[7] Pochanart, P., Akimoto, N., Khodzher, T., Kajii, Y. and Potemkin, V. (2003) Regional Background Ozone and Carbon Monoxide Variations in Remote Siberia (East Asia). . Journal of Geophysical Research, 108, 4028. http://dx.doi.org/10.1029/2001JD001412

[8] Hirano, K., Maeda, H. and Saito, K. (2002) Methods for Measurement of NO, $\mathrm{NO}_{2}, \mathrm{SO}_{2}, \mathrm{O}_{3}$ and $\mathrm{NH}_{3}$ Concentration by Means of Passive Samplers (in Japanese). Yokohama Environmental Science Research Institute, Yokohama City, Kanagawa Pref. Japan, 52 p.

[9] Ohizumi, T., Nagai, T., Golobokova, T., Toruksa, W. and Meng, X. (2013) Joint Research Project for Developing Low Cost Methodology on Gas Concentration Monitoring in East Asia. EANET Science Bulletin, 3, 135-145.

[10] (2001) Protocol for Ozone Measurement Using the Ozone Passive Sampler Badge (Revision 3). Ogawa \& Co., Inc., Harvard School of Public Health, Boston, 16 p.

[11] (2013) Technical Manual for Air Concentration Monitoring in East Asia/Scientific Advisory Committee of EANET at Its Thirteenth Session. Network Center for EANET, Niigata-shi, 155 p.

[12] Kholyavitskaya, A.A., Potemkin, V.L., Golobokova, L.P. and Khodzher, T.V. (2011) Measurements of Concentrations of Surface Ozone Using Passive Sampling. Optics of Atmosphere and Ocean, 24, 828-831.

[13] Latysheva, I.V., Makukhin, V.L. and Potemkin, V.L. (2005) Studies of Characteristics of the Asian Maximum and Its Effect on Atmosphere Pollution in the Area of Lake Baikal. Optics of Atmosphere and Ocean, 18, 466-470.

[14] Demin, V.I. and Beloglazov, M.I. (2004) On Effect of Local Circulation Processes on Dynamics of Surface Ozone. Optics of Atmosphere and Ocean, 17, 331-333.

[15] Demin, V.I., Beloglazov, M.I. and Elansky, N.F. (2002) On Relationship between Ozone Concentration and Height of Mixing Layer. Optics of Atmosphere and Ocean, 17, 662-665.

[16] Belan, B.D. (2009) Tropospheric Ozone. Gases_Precursors of Ozone. Optics of Atmosphere and Ocean, 22, $230-253$.

[17] Butukhanov, V.P., Zhamsueva, G.S., Zayakhanov, A.S., Lomukhin, Y.L. and Tsydypov, B.Z. (2002) Specific Distribution of Surface Concentrations of Ozone and Nitrogen Oxides during Photochemical Processes Occurring in the Baikal Region. Optics of Atmosphere and Ocean, 15, 604-607.

[18] Obolkin, V.A., Potemkin, V.L., Makukhin, V.L., Chipanina, Y.V. and Marinayte, I.I. (2014) Low-Level Atmospheric Jets as Main Mechanism of Long-Range Transport of Power Plant Plumes in the Lake Baikal Region. International Journal of Environmental Studies, 71, 391-397.

[19] Cocks, A.T., Kallend, A.S. and Marsh, A.R.W. (1983) Dispersion Limitations of Oxidation in Power Plant Plumes during Long-Range Transport. Nature, 305, 122-123. http://dx.doi.org/10.1038/305122a0

[20] WMO WDGG Data Summery (2015) WDCGG, No 39, Published by Jap Meteor Agency, 124 p. 